\title{
Model Manajemen Produksi Film Dokumenter Bulu Mata Karya Tonny Trimarsanto
}

\author{
Khalda Ahmad Muafa ${ }^{1}$ dan Fajar Junaedi ${ }^{2 *}$ \\ 1,2 Universitas Muhammadiyah Yogyakarta \\ E-mail:kahmadmuafa@gmail.com¹ dan fajarjun@umy.ac.id²* \\ *corresponding author
}

Keywords:

Model ,Production

Management, Documentary Film, Bulu Mata.

Kata Kunci:

Model, Manajemen

Produksi, Film Dokumenter, Bulu Mata.

\begin{abstract}
This research discusses about production management of a documentary film Bulu Mata which was produced in collaboration between an organization called Suara Kita and Rumah Dokumenter to raised the issues of transgender. This research aim to find out how the production management model used in the pre-production, production, and post-production during the filmmaking process. This research used a positivistic approach with case study method. The research data obtained from in-depth interview, documentation, and literature. The result showed this film in the pre production step, planning the idea with other filmmakers and Suara Kita, how to focus objectives of the film, do field research to obtain the data needed, choose the storytelling in the film, production planning, budgeting production, preparing the equipment, and management of the film crew. In the production step are so important to do briefing with the subject film before taking the video, and the cameraman know how to take procedures as shot size, camera angle, continuity, and good image composition. In the final process, post-production step starts from editing which includes editing script, transcript of interview result, checking shooting report, selecting the video according to editing script, narration, and choose the atmosphere sound. And then do discussion between the director and editor regarding the video to be selected, joint preview to correct the lack of continuity in the film and immediate revision of the film.
\end{abstract}

\begin{abstract}
ABSTRAK
Penelitian ini membahas tentang manajemen produksi film dokumenter berjudul Bulu Mata yang diproduksi kerjasama antara organisasi bernama Suara Kita dengan Rumah Dokumenter yang mengangkat isu transgender. Penelitian ini bertujuan untuk mengetahui bagaimana model manajemen produksi yang digunakan pada tahap pra produksi, produksi, dan pasca produksi selama proses pembuatan film tersebut. Hasil penelitian menunjukkan film Bulu Mata pada tahap pra produksi yaitu melakukan perencanaan ide dengan pegiat film lain serta pihak Suara Kita, bagaimana memfokuskan tujuan dari film, bergegas melakukan riset lapangan agar mendapatkan data yang dibutuhkan, menentukan pendekatan bercerita, perencanaan produksi, pendanaan produksi, mempersiapkan peralatan dan manajemen kru film tersebut. Dalam tahap produksi film dokumenter sangat penting untuk melakukan briefing dengan subjek film sebelum melakukan pengambilan gambar, serta kameramen mengetahui bagaimana prosedur dalam pengambilan gambar seperti shot size, camera angle, kontiniti dan komposisi gambar yang baik. Dalam proses akhir, tahap pasca produksi yaitu mulai dari editing yang di dalamnya meliputi naskah editing, transkrip hasil wawancara, mengecek shooting report, pemilihan gambar sesuai dengan naskah editing, narasi, dan suara atmosfer. Kemudian melakukan diskusi antara sutradara dan editor terkait gambar yang akan dipilih, juga sekaligus preview bersama untuk mengoreksi kurangnya kontiniti dalam film dan segera revisi film tersebut.
\end{abstract}

Copyright (C) 2020 Channel Jurnal Komunikasi. All right reserved. 


\section{PENDAHULUAN}

Media massa adalah sebuah media untuk berkomunikasi dan menyebarkan informasi secara luas dan dapat dikonsumsi secara massal oleh masyarakat bukan ditujukan untuk konsumsi pribadi saja (Bungin, 2006). Film merupakan salah satu bagian dari media massa, film berperan sebagai sarana komunikasi yang digunakan untuk penyebaran hiburan, menyajikan cerita, peristiwa, musik, drama dan sajian lainnya kepada masyarakat (Toni, 2015). Didalamnya film dapat mengkonstruksi nilai-nilai sosial dan dapat digunakan sebagai media untuk menyampaikan ideologi. Film juga dapat digunakan sebagai media untuk menyampaikan kritik sosial yang ada di masyarakat, serta memberikan penguatan terhadap gagasan atau ideologi yang sudah ada sebelumnya. Kemudian film juga penting dalam memperlihatkan aspek kenikmatan sebuah tontonan yang disajikan di layar yang mana didalamnya audiens mengenali bintang film, gaya dan genre (Junaedi, 2016).

Film diketahui mempunyai beberapa genre yang paling digemari audiens yaitu drama, horor, aksi, sejarah, percintaan dan komedi (Marta \& Suryani, 2016). Ada satu genre yang sangat awam bagi kebanyakan orang yaitu film dokumenter karena dari segmentasi penontonnya berbeda dengan film fiksi atau film yang dikomersilkan. Film dokumenter dianggap oleh sebagian orang sebagai tayangan berdurasi panjang yang menampilkan beauty shots, dan sebagian lagi menyebut film dokumenter mempertontonkan tentang faktual secara detail serta orang melihat dokumenter sebagai sebuah video yang bercerita tentang satwa liar dan kehidupan suku pedalaman (Jauhari, 2012).

\section{Gambar 1. Poster Film Dokumenter Bulu Mata}

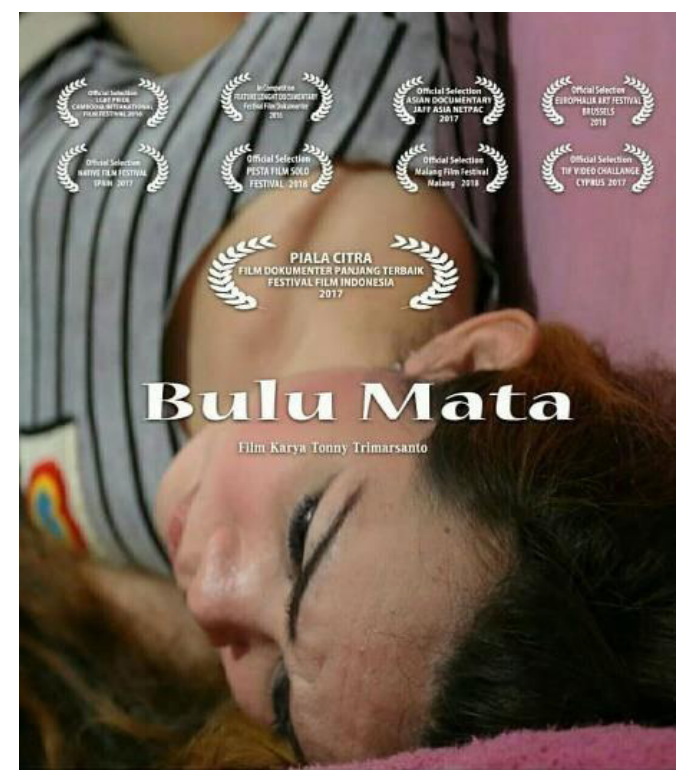

Film dokumenter "Bulu Mata" merupakan film yang disutradarai oleh Tonny Trimarsanto yang berdurasi 61 menit. Film ini diproduksi oleh Rumah Dokumenter dan Suara Kita selama kurun waktu hampir 1 tahun lamanya. Film ini menceritakan latar belakang keseharian kelompok transgender di Aceh yang hidup bersama dalam sebuah salon kecantikan menjadi pilihan tempat tinggal sekaligus tempat mereka mencari uang.

Terciptanya film dokumenter "Bulu Mata" yakni karena memiliki tujuan yaitu kampanye dalam menyuarakan hak-hak manusia yang jauh dari kata prioritas. Film ini hadir untuk memberikan satu pengalaman kepada banyak keluarga jika salah satu dari anggota keluarganya ada yang ingin jadi transgender itu akan seperti apa terutama di lingkungannya. Terkait dengan hal tersebut, film ini dipertontonkan di banyak kota dengan tujuan untuk berbagi pengalaman yakni salah satu dari anggota keluarganya ada yang menjadi transgender dan sebagai bentuk meluruskan stigma negatif terhadap transgender.

Film ini pernah berpartisipasi dalam kompetisi film dokumenter panjang di ajang Festival Film Dokumenter (FFD) pada tahun 2016 dan juga berhasil meraih penghargaan Piala Citra dengan kategori film dokumenter panjang terbaik di ajang Festival Film Indonesia (FFI) pada tahun 2017 serta banyak festival yang didapat dari mulai festival nasional hingga internasional.

Pembuatan film dokumenter "Bulu Mata" menjalankan proses produksi yang cukup panjang sehingga manajemen produksi berperan aktif dalam proses produksinya. Manajemen produksi adalah seluruh kegiatan yang berkesinambungan dengan pengelolaan (manajemen) produksi dengan tujuan untuk menciptakan sebuah karya berdasarkan rancangan ide produksi itu sendiri (Rahmitasari, 2017). 
Terkait dengan model, menciptakan sebuah karya berupa film bukanlah hal yang mudah. Manusia memahami pengalaman mereka melalui makna-makna yang ditemukan dalam simbol-simbol sehingga dapat membentuk pola pikir seseorang berubah seiring berproses dalam kehidupan sosial (Kholisoh \& Primayanti, 2016). Sutradara memiliki pengalaman tersendiri dengan menggunakan model produksi yang ideal. Model yang dipakai oleh sutradara juga tidak terlepas dari film-film sebelumnya yakni secara konsep yang terarah.

Dalam penelitian ini penulis melihat dari berbagai sumber seperti buku maupun jurnal. Penulis menemukan beberapa penelitian terdahulu dengan objek yang berbeda-beda. Penelitian akan dijabarkan dalam tabel dibawah sebagai berikut:

Tabel 1. Persamaan dan Perbedaan dengan Peneliti Terdahulu

\begin{tabular}{|l|l|}
\hline Judul Penelitian & Manajemen Produksi Film Dokumenter Pendek "ASU (PROKONTRA)" \\
\hline Tahun Penelitian & 2019 \\
\hline Sumber & Repository Universitas Muhammadiyah Yogyakarta \\
\hline Nama Peneliti & Pipiet Setyaningsih \\
\hline Bahasan & Membahas tentang manajemen produksi film dokumenter "ASU (PROKONTRA)" \\
\hline Persamaan & Sama-sama membahas tentang film dokumenter \\
\hline & \multicolumn{2}{|l|}{} \\
\hline Judul Penelitian & Manajemen Produksi Film Dokumenter "Dluwang" \\
\hline Tahun Penelitian & 2018 \\
\hline Sumber & Repository Universitas Muhammadiyah Yogyakarta \\
\hline Nama Peneliti & Mohammad Iqbal \\
\hline Bahasan & $\begin{array}{l}\text { Membahas terkait manajemen produksi dari pra produksi, produksi, sampai pasca } \\
\text { produksi film "Dluwang" }\end{array}$ \\
\hline Persamaan & Sama-sama membahas tentang film dokumenter \\
\hline \multicolumn{2}{|l}{} \\
\hline Judul Penelitian & Manajemen Produksi Dokumenter Televisi Program "Rupa Indonesia" TvOne \\
\hline Tahun Penelitian & 2017 \\
\hline Sumber & Repository Universitas Muhammadiyah Yogyakarta \\
\hline Nama Peneliti & Muhammad Naufal \\
\hline Bahasan & $\begin{array}{l}\text { Membahas bagaimana manajemen produksi dokumenter televisi program "Rupa } \\
\text { Indonesia" yang ada di TvOne }\end{array}$ \\
\hline Persamaan & Sama-sama membahas tentang film dokumenter \\
\hline
\end{tabular}

Berdasarkan uraian di atas, peneliti tertarik untuk meneliti seperti apa manajemen produksi yang diterapkan dalam proses pembuatan film Bulu Mata pada saat tahap pra produksi, produksi, dan pasca produksi.

\section{METODE PENELITIAN}

Penelitian ini menggunakan pendekatan positivistik dengan metode studi kasus. Studi kasus tunggal adalah metode yang digunakan dengan tujuan menganalisis bagaimana orang-orang membingkai dan menyelesaikan masalah (Endah, 2011). Teknik pengumpulan data yang digunakan yaitu wawancara mendalam, dokumentasi, dan literatur yang relevan. Informan dalam penelitian ini adalah kru yang terlibat dalam pembuatan film Bulu Mata seperti sutradara, kameramen, dan editor. Selanjutnya teknik analisis data dimulai ketika peneliti mengecek berbagai data yang berhasil dikumpulkan oleh peneliti di lapangan dengan melakukan wawancara dengan informan yang mengetahui jalannya produksi film tersebut. Peneliti mengulang hasil wawancara dan mulai menganalisa data dari mentranskrip hasil wawancara dengan memutar kembali recorder hasil wawancara dan mendengarkan baik-baik dan mencatat kata-kata yang penting yang disebutkan oleh informan dalam rekaman wawancara tersebut.

Kemudian menganalisa melalui data dokumentasi yang didapat, peneliti biasanya mencari dokumentasi atau meminta kepada informan apabila ada data yang kurang lengkap. Peneliti dapat menganalisa dari data dokumentasi melalui arsip atau dokumen produksi film, serta data dari informan atau internet merujuk soal produksi film tersebut. Peneliti menggunakan data dokumentasi ini sehingga penelitian ini dapat terlengkapi karena sumber yang bisa didapatkan dari mana saja. Selanjutnya data juga dapat dianalisa dengan cara mengkorelasikan data-data yang didapat dengan literatur-literatur yang menyangkut dengan teori dalam buku tersebut dengan menggunakan model "Miles \& Huberman yaitu reduksi data, sajian data, serta penarikan kesimpulan dan verifikasi (Sugiyono, 2005). 


\section{HASIL DAN PEMBAHASAN}

Tahap pra produksi yaitu menciptakan ide, fokuskan tujuan pembuatan film, riset online atau observasi lokasi, memilih pendekatan bercerita film, perencanaan produksi, penyusunan anggaran produksi, peralatan, dan manajemen kru yang baik (Junaedi, 2011).

Tabel 2. Alur Pra Produksi Film Bulu Mata

\begin{tabular}{|c|c|}
\hline $\begin{array}{l}\text { Pengemasan } \\
\text { Ide Film }\end{array}$ & $\begin{array}{l}\text { - } \quad \text { Ide didapat dari sebuah organisasi pejuang transgender yaitu Suara Kita } \\
\text { - } \quad \text { Rapat dengan pegiat film dan pihak Suara Kita }\end{array}$ \\
\hline $\begin{array}{l}\text { Tujuan Pembuatan } \\
\text { Film Dokumenter }\end{array}$ & $\begin{array}{l}\text { - Menyuarakan hak-hak transgender tanpa adanya batasan oleh } \\
\text { pemerintahan atau pihak yang melarang kelompok transgender itu hadir }\end{array}$ \\
\hline Melakukan Riset & $\begin{array}{ll}\text { - } & \text { Observasi lingkungan. } \\
\text { - } & \text { Wawancara non formal. } \\
\text { - } & \text { Mencari subjek yang sesuai dengan topik. }\end{array}$ \\
\hline $\begin{array}{l}\text { Pendekatan } \\
\text { Bercerita }\end{array}$ & $\begin{array}{ll}\text { - } & \text { Expository } \\
\text { - } & \text { Observasional }\end{array}$ \\
\hline $\begin{array}{l}\text { Perencanaan } \\
\text { Produksi }\end{array}$ & $\begin{array}{ll}\text { - } & \text { Data riset lengkap } \\
\text { - } & \text { Karakter yang sesuai topik } \\
\text { - } & \text { Lokasi yang aman } \\
\text { - } & \text { Pendekatan bercerita sudah ditentukan } \\
\text { - } & \text { Jadwal shooting } \\
\text { - } & \text { Budget produksi siap }\end{array}$ \\
\hline Budget Produksi & $\begin{array}{l}\text { - } \quad \text { Dana kreatif } 40 \text { juta untuk sewa alat, editor, dan sutradara } \\
\text { - } \quad \text { Transportasi dan tempat tinggal di urus oleh pihak Suara Kita }\end{array}$ \\
\hline Peralatan & $\begin{array}{ll}\text { - } & \text { Audio recorder } \\
\text { - } & \text { Lampu LED } 2 \text { buah } \\
\text { - } & \text { Gopro } \\
\text { - } & \text { Kamera 5D } \\
\text { - } & \text { Lensa fix, tele, wide }\end{array}$ \\
\hline Manajemen Kru & $\begin{array}{ll}\text { - } & \text { Jobdesk yang fungsional yaitu Additional } \\
\text { - } & \text { Editor }\end{array}$ \\
\hline
\end{tabular}

Film Bulu Mata yaitu film kerjasama antara LSM Suara Kita dengan Rumah Dokumenter yang memberikan wewenang sepenuhnya untuk membuatkan film tentang transgender tersebut. Pada pra produksi ini mendapatkan ide bukanlah hal yang mudah, ide didapat dari banyak hal yaitu kehidupan sehari-hari yang merupakan sumber inspirasi paling mudah mendapatkan sebuah ide. Banyak orang dalam kehidupan sehari-hari terlibat interaksi sosial, maka semakin mudah untuk mengembangkan sebuah ide. Buku, media massa dan internet juga dapat dijadikan alternatif dalam pencarian ide (Junaedi, 2011: 9). Sedangkan menurut Nugroho (2007: 43-50) suatu ide dapat ditemukan dengan banyak hal. Berikut beberapa cara mendapatkan ide: 1) Kadang Ide Datang Begitu Saja. 2) Ide di Sekeliling Kita. 3) Ide juga Tersedia di Pinggir Jalan. 4) Ide Biasa menjadi Istimewa. 5) Ide Istimewa menjadi Biasa. 6) Ide Tersaji Setiap Hari. 7) Ide sangat Berharga. Film Bulu Mata awalnya ide tersebut didapat dari seorang teman yang memperjuangkan persoalan transgender kemudian dipilih dari pihak Rumah Dokumenter untuk menjadi sutradara film oleh Suara Kita dan berlanjut pada pembahasan ide gagasan melalui rapat dengan beberapa pegiat film lainnya. Ide film dokumenter bisa berasal dari manapun, tanpa ada batasan ruang dan waktu. Bisa berasal dari orang lain, lalu pembuat film mencoba untuk menindaklanjutinya. Selain diadakannya rapat, ide juga dapat dikembangkan melalui majalah, koran, radio, dan televisi. Sumber-sumber inilah yang dijadikan amunisi pembuat film (Tonny, 2011: 11).

Kemudian langkah selanjutnya dalam pembuatan film dokumenter yaitu memfokuskan tujuan film tersebut. Adanya tujuan merupakan suatu hal yang harus dihadirkan dalam film dan tujuan tersebut berhasil tersampaikan pada penontonnya. Pembuat film harus tahu dan juga memutuskan tujuan dalam pembuatan film dokumenter yakni dengan bertanya pada diri sendiri cerita apa yang akan diceritakan kepada penonton dan mengapa perlu diceritakan kepada penonton melalui film yang akan dibuatnya nanti. Dengan menentukan statemen, maka sebuah tujuan yang dirancang akan terlihat lebih jelas dan matang (Junaedi, 2011: 11). Dibuatnya film Bulu Mata yaitu dengan tujuan untuk mengkampanyekan dalam menyuarakan hak-hak transgender yang ingin hidup seperti manusia pada umumnya. Tanpa adanya batasan oleh pemerintahan atau pihak yang melarang kelompok transgender itu hadir di suatu tempat. Jadi adanya tujuan film yaitu pesan utama yang hendak disampaikan melalui film. Tujuan tersebut akan menjadi hipotesa kerja atau dugaan sementara yang dipakai untuk merancang elemen-elemen penting yang saling berinteraksi dalam film (Tonny, 2011: 20).

Tahap pra produksi pembuatan film dokumenter melibatkan riset. Riset yaitu hal terpenting dalam proses mematangkan sebuah ide yang didapat. Riset dapat dilakukan dengan berbagai cara dan metode seperti studi pustaka, observasi lingkungan, serta wawancara dengan narasumber. Riset menjadi aspek yang tak terlepas dalam rangkaian pembuatan film dokumenter. Dengan adanya riset akan lebih memudahkan kerangka berpikir dalam membuat film 
dokumenter (Junaedi, 2011: 13-16). Sedangkan menurut Nugroho (2007: 70-76) riset dapat dilakukan dengan banyak cara yaitu 1) Koran, Buku dan Internet. 2) Terjun Lokasi. 3) Mencari Karakter Utama Film. 4) Mengkondisikan Lingkungan. 5) Melakukan Riset Visual. 6) Menjadi Filmmaker. Film Bulu Mata melakukan riset dengan beberapa tipe yaitu observasi lingkungan, wawancara non formal dengan banyak subjek dan sekaligus mencari karakter yang sesuai untuk disajikan dalam film tersebut. Riset adalah upaya mengumpulkan fakta dan data tentang apa yang diinginkan dalam film nantinya. Riset lapangan yaitu dengan melakukan pengumpulan data-data yang sesuai dengan ide cerita dengan mewawancarai orang yang relevan dengan ide film, mencari dan melakukan seleksi tokoh yang nanti akan menjadi juru bicara dalam film, dan mengkalkulasikan lokasi shooting untuk kebutuhan teknis gambar dan suara (Tonny, 2011: 21).

Kemudian dalam tahap pra produksi menentukan pendekatan apa yang hendak diangkat dalam bercerita kepada khalayak menjadi aspek penting dalam film dokumenter. Teknik bercerita apa dan elemen apa yang ingin digunakan, bisa dilihat dari pendekatan yang digunakan juga. Berikut ini adalah beberapa pendekatan cerita menurut Junaedi (2011: 17-19) yang dapat digunakan dalam film dokumenter: 1) Narasi. 2) Renacments. 3) Animasi. 4) Dokudrama. 5) Cinema Verite. 6) Filmmaker menjadi Bagian dari Film. 7) Wawancara. 8) Arsip Footage. 9) Arsip Foto. Sedangkan menurut Nichols (2001: 99) dokumenter mempunyai beberapa tipe genre diantaranya: 1) Poetic. 2) Expository. 3) Parcipatory. 4) Observational. 5) Reflexive. 6) Performative. Film Bulu Mata sendiri menggunakan teknik pendekatan bercerita Expository dan Observasional. Expository adalah bentuk dokumenter yang menampilkan pesan kepada penonton secara langsung melalui narasi berupa teks maupun suara. Sedangkan observasional yaitu utamanya merekam kejadian secara spontan dan natural yang akan diterima sebagai bagian dari kehidupan subjeknya (Trimarsanto, 2011: 7-9).

Selanjutnya memasuki tahap perencanaan produksi yang merupakan aspek terpenting sebelum dilakukannya pengambilan gambar. Perencanaan produksi merupakan jalan panduan untuk menjadikan film dokumenter benar-benar terealisasi. Jika tidak memiliki perencanaan produksi yang baik maka akan menemukan beragam kesulitan pada saat produksi film dokumenter, mulai dari manajemen produksi, manajemen kru, manajemen peralatan dan sebagainya. Perencanaan produksi film dokumenter yang diperlukan bukan hanya soal niat, kamera, dan kaset lalu pembuat film bisa langsung pergi shooting. Tetapi, bagaimana mempersiapkan kepentingan yang lain agar semuanya benar-benar matang dan dapat terealisasi dengan baik (Tonny, 2011: 45). Film Bulu Mata pada perencanaan produksi sudah sangat matang dilihat dari riset lapangan yang berkali-kali, kemudian pemilihan karakter yang sudah siap, pemilihan lokasi yang sudah diperkirakan, menentukan pendekatan cerita film, jadwal shooting, serta budget produksi yang sudah diatur dengan baik. Dalam rencana produksi ini harus sudah matang dalam segala hal meliputi data yang didapat saat riset sudah layak untuk dijadikan aspek yang bisa diangkat dalam film dokumenter, kemudian pilihan narasumber yang tepat memiliki kualifikasi berbicara mengenai topik yang diangkat, pilihan lokasi untuk pengambilan gambar berpengaruh pada manajemen produksi nantinya, serta pemilihan pendekatan apa yang akan dipakai untuk film dokumenter (Junaedi, 2011: 20).

Dalam membuat film dokumenter pastinya juga membutuhkan budget untuk selama kegiatan dari pra produksi hingga pasca produksi. Sebenarnya seluruh tahapan produksi yang telah dibahas sebelumnya diperlukan untuk menyusun budget produksi. Setiap pembuat film dokumenter harus melalui seluruh tahapan untuk bisa mendapatkan informasi penting dalam penyusunan budget. Akan tetapi, sangat jarang ada produksi yang mendapatkan dana sesuai dengan budget yang telah disusun.

Seringkali sebuah produksi harus berhadapan dengan jumlah dana yang jauh di bawah budget yang sudah dirancang (Tonny, 2011: 66). Informan menjelaskan tidak terlalu penting membicarakan soal budget di awal karena yang harus direalisasikan film tersebut bisa jadi dan dinikmati oleh penonton. Dana yang diberikan oleh LSM tidak terlalu besar akan tetapi dapat digunakan sebaik mungkin.

Produksi ini untuk kreatif kisaran 40 juta. Kreatif itu termasuk sewa alat, editor, dan sutradara. Penyediaan akomodasi penerbangan dan tempat tinggal di lokasi shooting itu merupakan tanggung jawab pihak Suara Kita. Kebutuhan dana muncul saat memulai riset sampai pada produksi membutuhkan alat serta pasca produksi masih juga dibutuhkan dalam proses editing. Keperluan dana produksi memang sudah muncul pada saat riset dimulai. Saat produksi juga biaya akan semakin membengkak. Kebutuhan peralatan shooting, konsumsi, dan sebagainya menjadi poin penting yang harus diperhatikan. Kemudian saat pasca produksi, biaya juga masih dibutuhkan dalam proses editing (Junaedi, 2011: 22).

Setelah pembuat film sudah tahu betul bagaimana alur cerita yang akan disajikan, tahap berikutnya adalah menyiapkan peralatan sesuai dengan kebutuhan yang dibutuhkan. Perlengkapan peralatan produksi yang harus disiapkan seperti kamera, bagian-bagian kamera, alat penyangga kamera, dan peralatan lainnya (Junaedi, 2011: 24). Tidak perlu membawa banyak alat yang penting bagaimana memaksimalkan penggunaan alat tersebut bisa digunakan sebaik mungkin. Untuk keperluan shooting film Bulu Mata ini hanya membawa alat seperlunya dan kebetulan juga semua alat yang dibutuhkan dimiliki oleh Rumah Dokumenter sendiri. Alat yang dibawa antara lain audio recorder, lampu LED kecil 2 buah, gopro, kamera 5D dengan varian lensa seperti fix, tele, wide. Pemilihan alat tersebut merupakan sudah dipertimbangkan agar bobot selama proses shooting nantinya lebih ringan. Tujuannya adalah untuk menggunakan peralatan yang paling sederhana namun paling efektif yang menyesuaikan dengan tingkat kesusahan pengambilan gambar dan menyesuaikan anggaran (Rosenthal, 2002: 151). 
Sejumlah besar kesuksesan film bergantung pada pemilihan kru. Berbeda halnya dengan film dokumenter, kru memang penting agar dapat membantu selama kegiatan proses produksi akan tetapi dalam film dokumenter kru bukanlah yang pertama, melainkan ide yang menjadi gagasan utamanya. Menentukan seorang kru biasanya dilihat dari banyak atau sedikitnya budget yang dipunyai. Kru yang terlibat penting dalam film dokumenter yaitu seperti sutradara, produser, juru kamera, dan tim riset. Tidak menutup kemungkinan persoalan kru pada film dokumenter dapat dirangkap jobdesknya menjadi lebih minimalis (Junaedi, 2011: 26). Produksi film Bulu Mata hanya mencari kru yang dibutuhkan fungsionalnya saja, contohnya adanya additional editor yang membantu dalam proses editing untuk merapihkan urutan gambar agar menjadi lebih bercerita. Selebihnya persoalan kru di rangkap untuk lebih menghemat pengeluaran dana juga. Pemilihan kru yang tepat untuk membantu pekerjaan lebih cepat selesai itu suatu pilihan yang bagus. Kriteria dalam memilih kru itu bisa sangat fungsional. Dalam produksi dokumenter skala kru yang kecil juga sering dilakukan oleh kebanyakan pembuat film dokumenter (Rosenthal, 2002: 146).

\section{A. Tahap Produksi Film Bulu Mata}

Setelah semua proses pra produksi dirasa selesai dan dapat melanjutkan ke tahap berikutnya, maka tahap selanjutnya yaitu masuk pada tahap produksi yang mana semua yang sudah di rencanakan di tahap pra produksi dapat berjalan sesuai harapan. Di dalam produksi film Bulu Mata yaitu adanya persiapan dan pengecekan alat serta melakukan pengambilan gambar sesuai jadwal produksi yang ada.

Bagan 1. Alur Produksi Film Bulu Mata

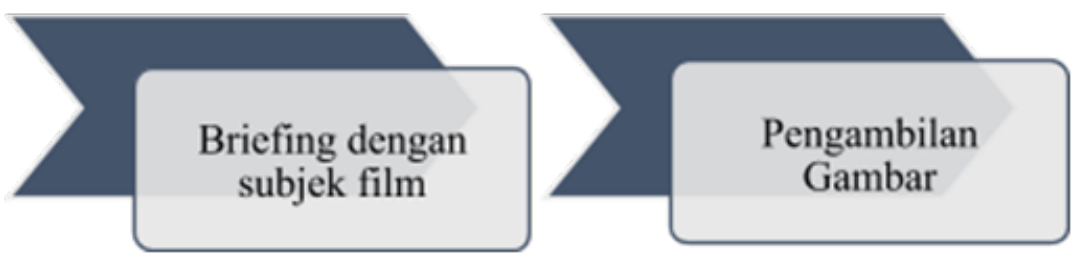

Produksi film dokumenter yaitu proses pengambilan gambar di lokasi shooting dengan merekam kejadian nyata yang sedang terjadi saat itu juga tanpa rekayasa dan arahan dari sutradara. Seluruh kru dan subjek di briefing sebelum melakukan pengambilan gambar sehingga dapat bekerja sesuai jadwal yang sudah ditentukan agar pembuatan film selesai tepat waktu. Film Bulu Mata melakukan briefing sebelum produksi dimulai. Alasan dilakukannya briefing antara pembuat film dan subjek adalah untuk meminimalisir waktu dan juga menghindari kesalahan yang terjadi saat pengambilan gambar berlangsung agar tidak hilang komunikasi dan arahan dari sutradara. Kunci dari melakukan briefing yaitu untuk membuat subjek berlaku natural dalam film dokumenter berpengaruh dari bagaimana kita mengarahkan mereka (Tonny, 2011: 90).

Kemudian mengenai pengambilan gambar yaitu bagaimana produksi tersebut dilakukan secara fleksibel mengikuti kegiatan para subjek di lapangan dan tidak mungkin juga melakukan pengambilan gambar ketika tidak ada momen di lapangan. Saat shooting biasanya melakukan wawancara tak berstruktur tergantung kebutuhan pada film. Biasanya wawancara dilakukan untuk mengorek keterangan seorang narasumber mengenai topik tersebut, baik secara langsung atau lewat berbagai teknik yang memanfaatkan kelengahan subjek. Secara singkat dapat dikatakan bahwa wawancara adalah sebuah proses mengangkat sesuatu yang ada di bawah permukaan (Rabiger, 1992: 139).

Keputusan pengambilan gambar yang dilakukan oleh sutradara sangat tepat. Penggunaan alat yang sesuai kebutuhan membuat lebih ringan dalam gerakan apapun sehingga momen bergerak begitu cepat seketika dapat direkam dengan hasil gambar yang baik. Kemudian pengambilan gambar biasanya mencoba merekam gambar dengan banyak pilihan dari posisi angle yang berbeda dan mengatur shot size lebih bervarian pilihan gambar serta menyesuaikan kontiniti gambar agar lebih mudah ketika masuk tahap editing. Pola tersebut dilakukan karena selama shooting sutradara itu sendirian. Dalam produksi film dokumenter, banyak aspek penting yang harus dimiliki oleh camera person dalam menghasilkan gambar terbaiknya seperti memahami tentang sinematografi, camera angle, shot size, gerakan kamera, kontiniti waktu dan ruang, serta komposisi gambar (Junaedi, 2011: 49-63).

\section{B. Tahap Pasca Produksi Film Bulu Mata}

Tahap yang terakhir adalah pasca produksi. Setelah melewati banyak kegiatan pada pra produksi sampai dengan produksi, kini waktunya untuk semua hasil gambar disusun menjadi satu. Tahap ini terdapat kegiatan yang dinamakan editing yaitu proses akhir dalam teknik produksi film dokumenter. Tanpa editing yang baik, film dokumenter tidak menarik untuk dipertunjukan kepada penonton, walaupun sebenarnya ada banyak stock shot yang menarik saat pengambilan gambar dan stock shot yang menarik tersebut sudah terekam. 
Bagan 2. Alur Pasca Produksi Film Bulu Mata

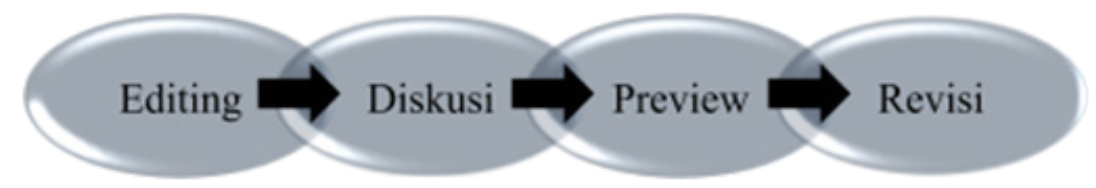

Editing dipahami sebagai sebuah rangkaian proses memilih, mengatur dan menyusun shotshot menjadi satu scene. Ini memperlihatkan bahwa tugas editor yaitu harus mampu menciptakan gambar dan suara agar berkesinambungan. Menurut Junaedi (2011: 66-67) dalam editing film meliputi banyak kegiatan seperti memilih shot, mempertimbangkan kontiniti, memilih transisi, membentuk irama dan tempo. Sedangkan Tonny (2011: 103-105) mengatakan ada beberapa langkah yang dapat dilakukan dalam kerja editing seperti mengecek shooting report, transkrip wawancara, membuat editing script, narasi, serta suara atmosfer dan musik. Film Bulu Mata dalam proses pasca produksi yaitu melakukan editing dengan sistem yang jelas meliputi adanya naskah, memilih gambar, transkrip wawancara, dan membuat editing script tersebut. Berdasarkan data yang didapat untuk proses pasca produksinya film Bulu Mata melakukan editing kemudian diskusi sekaligus preview bareng antara sutradara dan editor yang terlibat didalamnya. Tujuan dilakukannya preview bareng yaitu mengoreksi bila mana ada kekurangan atau editing yang kurang dapat direvisi kembali. Kegiatan editing ini dilakukan selama terus menerus walaupun tidak ada target waktu akan tetapi film Bulu Mata harus dikerjakan setiap waktu agar penyusunan gambar ke gambar tidak jumping dan akan menarik sampai ke penontonnya. Banyak orang menganggap fase pengambilan gambar menjadi akhir dari produksi film dokumenter. Proses akhir dari produksi film ada pada tahap pasca produksi yang mana menyatukan gambar yang dilakukan oleh editor. Sutradara tetap bertindak sebagai jembatan tetapi editor yang mengeksekusi pekerjaan tersebut. Hal terpenting adalah sutradara dan editor saling memahami sebagai tim pelengkap dalam film. Pekerjaan editor mencakup pemilihan gambar, melihat transkrip yang ada, memilih musik dan efek transisi, meletakkan narasi, sound mix serta melakukan preview dan revisi jika adanya revisi (Rosenthal, 2002: 199).

\section{KESIMPULAN}

Film Bulu Mata merupakan film dokumenter pesanan yang digarap oleh rumah produksi yang ada di Klaten yaitu Rumah Dokumenter. Tonny pemilik Rumah Dokumenter dipercayai oleh sebuah lembaga yang bernama Suara Kita untuk minta dibuatkan film yang berkaitan dengan perjuangan untuk kesetaraan dan keadilan bagi golongan transgender. Terciptanya film Bulu Mata karena proses awal pra produksi sampai tahap pasca produksi yang baik sehingga film tersebut dapat dinikmati oleh banyak orang. Dari hasil penelitian yang dilakukan maka ditarik kesimpulan sebagai berikut:

Model manajemen produksi yang didapat dari tahap pra produksi pembuatan film Bulu Mata yaitu awalnya ide didapat dari Suara Kita yang meminta bantuan Rumah Dokumenter untuk memproduksi film dengan ide tentang transgender. Setelah itu, ide tersebut digodok dengan dilakukannya pengemasan rencana produksi melalui sebuah rapat dengan pegiat film serta pihak pengurus dari Suara Kita sebelum masuk ke tujuan pembuatan film. Tujuan dibuatnya film ini yaitu kampanye dalam menyuarakan isu minoritas agar tidak ada jarak antara kaum minoritas dan mayoritas di sekitar. Setelah pengemasan ide dan tujuan terlewati, masuklah tahap riset agar ide dapat terus dikembangkan lebih dalam. Riset yang digunakan dalam film ini yaitu dengan cara observasi lingkungan dan wawancara non formal yang berbuah mendapatkan subjek sesuai dapat bercerita dalam film. Setelah riset dilakukan lalu pemilihan pendekatan bercerita pada film. Film Bulu Mata ini menggunakan pendekatan bercerita Expository dan Observasional. Selanjutnya sutradara membuat perencanaan produksi agar matang saat produksi nantinya. Perencanaan produksi film Bulu Mata ini sangat matang dalam hal meliputi riset yang sudah sesuai, pemilihan subjek cocok, lokasi pengambilan gambar, pemilihan pendekatan bercerita pada film, serta kesiapan jadwal shooting. Masuk pada budget produksi, pada bagian ini dana yang didapat dari Suara Kita tidak terlalu banyak. Jadi bagaimana harus sangat meminimalisir keperluan agar menjadi hemat. Kebutuhan budget biasanya termasuk sewa alat, sutradara, editor, konsumsi pribadi dan keperluan masih diperlukan sampai tahap editing. Untuk masalah transportasi penerbangan dan tempat tinggal semua diatur oleh pihak Suara Kita. Langkah berikutnya yaitu mempersiapkan peralatan untuk produksi di lapangan. Pada produksi film Bulu Mata ini menggunakan beberapa alat seperti audio recorder, lampu LED kecil 2 buah, gopro, kamera 5D dengan lensa seperti fix, tele, dan wide. Keperluan alat itu sudah cukup efektif untuk melakukan pengambilan gambar. Dan terakhir yaitu manajemen kru, film Bulu Mata tidak membutuhkan kru dengan skala yang besar tetapi bagaimana memaksimalkan kru dengan skala kecil terlebih jobdesknya sangat fungsional. Pemilihan kru seperti additional editor dalam film Bulu Mata ini tepat dan sekaligus meminimalisir pengeluaran dana produksi.

Tahap produksi film Bulu Mata berjalan lancar sesuai dengan perencanaan yang disusun. Hal ini dapat dilihat mulai dari bagaimana kesiapan sutradara dalam pengambilan gambar serta melakukan pengarahan terhadap subjek agar jalannya shooting tidak ada halangan. Film Bulu Mata ini diproduksi dengan menggunakan lensa wide karena shooting dilakukan sendiri dan momen yang bergerak begitu cepat. Lensa wide lebih mudah digunakan karena tidak perlu mengatur 
fokus, detail sudah bisa mendapatkan gambar yang maksimal. Untuk menentukan shot size, camera angle, kontiniti, dan komposisi gambar yang baik, ada pola yang selama produksi dilakukan oleh sutradara yaitu dengan banyak mencoba merekam dari banyak posisi seperti angle yang berbeda-beda kemudian menemukan kontiniti yang sesuai serta shot size dengan banyak mengambil gambar sehingga pilihan gambar lebih varian dalam editing nantinya.

Tahap terakhir dari sebuah manajemen produksi yaitu pasca produksi. Pada tahap ini merupakan dilakukannya editing sesuai catatan yang dimiliki. Tahap pasca produksi film Bulu Mata saat editing dimulai dari desain struktur penyusunan gambar, timeline, memilih gambar, memilih narasi, transkrip wawancara, serta editing script yang lebih variasi bisa di bolak balik juga melakukan diskusi untuk kematangan pemilihan gambar dan menyesuaikan alur cerita karena pada film dokumenter ini naskah dapat dibolak-balik mengurutkan gambar kembali. Preview bareng antara sutradara dengan editor jika ada kesalahan yang harus direvisi maka harus diperbaiki kembali. Masukan dari preview bareng yang dapat menjadi perbaikan susunan cerita untuk mendapatkan hasil yang lebih baik. Revisi juga lebih mudah dikerjakan karena sutradara beserta editor yang mengontrol kegiatan editing untuk film Bulu Mata tersebut.

\section{DAFTAR PUSTAKA}

[1] Bungin, Burhan. (2006). Sosiologi Komunikasi: Teori, Paradigma, dan Diskursus Teknologi Komunikasi di Masyarakat. Jakarta: Kencana Prenada Media Group.

[2] Endah P, Chatarina. (2011). Memahami Studi Kasus sebagai Metode Penelitian, dalam Ishak, Aswad;

[3] Junaedi, Fajar; Budi HH, Setio; Prabowo, Agung [ed] (2011). Mix Methodology dalam Penelitian Komunikasi. Yogyakarta: ASPIKOM.

[4] Jauhari, Haris. (2012). Jurnalisme Televisi Indonesia: Tinjauan Luar Dalam. Jakarta: Kepustakaan Populer Gramedia.

[5] Junaedi, Fajar. (2011). Membuat Film Dokumenter. Yogyakarta: Lingkar Media.

[6] Junaedi, Fajar. (2016). Menikmati Budaya Layar, Membaca Film. Yogyakarta: Buku Litera.

[7] Kholisoh \& Primayanti. (2016). Model Komunikasi Kelompok Tentang Makna Pernikahan Antargenerasi di Kalangan Kelas Menengah Jakarta. Jurnal ASPIKOM, 3(1), 123.

[8] Marta \& Suryani. (2016). Dampak Kekuatan Informasi Film "Ngenest” Terhadap Penilaian Komunitas Stand Up Indonesia Jakarta. Jurnal ASPIKOM, 3(1), 78.

[9] Nichols, Bill. (2001). Introduction to Documentary. USA: Indiana University Press.

[10] Nugroho, Fajar. (2007). Cara Pinter Bikin Film Dokumenter. Yogyakarta: Percetakan Galang Press.

[11] Rabiger, Michael. (1992). Directing Documentary. Boston-London: Focal Press.

[12] Rahmitasari, Diyah Hayu. (2017). Manajemen Media di Indonesia. Jakarta: Yayasan Pustaka Obor Indonesia.

[13] Rosenthal, Alan. (2002). Writing, Directing, and Producing Documentary Films and Videos. United States of America: Southern Illinois University Press.

[14] Sugiyono. (2005). Memahami Penelitian Kualitatif. Bandung: Alfabeta.

[15] Toni, Ahmad. (2015). Peran Film Sebagai Media Sosialisasi Lingkungan. Jurnal Komunikator Universitas Muhammadiyah Yogyakarta, 7(1), 42.

[16] Trimarsanto, Tonny. (2011). Renita, Renita: Catatan Proses Membuat Film Dokumenter. Klaten: Rumah Dokumenter.

[17] Trimarsanto dan tim. (2011). Pemula dalam film dokumenter gampang-gampang susah. Jakarta: In-Document. 